\title{
The Effect of Mentha Pulegium on Healing of Burn Wound Injuries in Rat
}

\author{
Reza Vaghardoost ${ }^{1}$, Yaser Ghavami ${ }^{2}$, Behnam Sobouti ${ }^{3 *}$
}

1. Department of Aesthetic and Reconstructive Surgery, Shahid Motahari Burn Hospital, Iran University of Medical Sciences, Tehran, Iran;

2. Burn Research Center, Shahid Motahari Hospital, Iran University of Medical Sciences, Tehran, Iran;

3. Department of Pediatric Infectious Diseases, Burn Research Center, Shahid Motahari Burns Hospital, Iran University of Medical Sciences, Tehran, Iran

*Corresponding Author:

Behnam Sobouti, MD;

Associate Professor of Pediatric Infectious Diseases,

Burn Research Center,

Shahid Motahari Burns Hospital, Iran University of Medical Sciences, Tehran, Iran.

E-mail: sobouti.b@iums.ac.ir

Received: December 8, 2017

Revised: October 23, 2018

Accepted: November 2, 2018

\section{ABSTRACT}

\section{BACKGROUND}

Burn is one of the most common injuries and the 4th common cause of trauma globally. This study was designed to evaluate the effect of the Mentha pulegium extract on second degree burn injuries in rats assessing histopathologic and macroscopic.

\section{METHODS}

M. Pulegium extract dressings was used as a treatment to deep dermal contact burns in rats, compared with two control groups of vaseline dressing and simple dressing by normal saline. After creating seconddegree burn on the dorsum of rats, the treatments were applied for 15 min in three groups. Wound dressings were performed on days $1,3,7,14$ and $21^{\text {st }}$ and at the same time macroscopic assessment was performed using a digital camera and software processing of photos. Pathologic evaluation of skin specimens was undertaken on days 1, $3,7,14$ and $21^{\text {st }}$. Wound healing parameters such as epithelialization, angiogenesis, granulation tissue formation, inflammatory cells were compared between these 3 groups.

\section{RESULTS}

Application of M. Pulegium extract on second degree burn wounds significantly decreased burn surface area and increased fibroblasts in comparison to simple dressing. There was not any statistically significant relationship between M. Pulegium extract treated group and vaseline treated or simple dressing groups on other wound healing parameters.

\section{CONCLUSION}

This study delineated that M. Pulegium extract had a positive effect on healing process of second degree burns.

\section{KEYWORDS}

Mentha pulegium; Burn; Wound; Healing; Rat

Please cite this paper as:

Vaghardoost R, Ghavami Y, Sobouti B. The Effect of Mentha Pulegium on Healing of Burn Wound Injuries in Rat. World J Plast Surg 2019;8(1):43-50. doi: 10.29252/wips.8.1.43.

\section{INTRODUCTION}

Burn is one of the most common injuries and the $4^{\text {th }}$ common cause of trauma globally. ${ }^{1}$ Burn injuries can lead to serious morbidities such as infections, scars and disabilities; as well as psychosocial and economical problems. ${ }^{2}$ In a study in United States, approximately 700000 individuals referred to the 
emergency wards seeking treatment for burn injuries and amongst them, 45000 injured patients needed hospitalization., ${ }^{3,4}$ In Iran, the mortality rate was shown to vary from 1.4 to 9.7 per one hundred thousand. ${ }^{5}$

Management and treatment of burn injuries are various and numerous in different countries and cultures. ${ }^{6}$ However, the mainstay of therapy is to resuscitate patients with fluid and prevent the infections of the burn wounds until the body regenerates the damaged tissues and skin. During the years, specific herbals have been developed and used to facilitate and accelerate the process of healing and tissue regeneration. There are some studies that explain alternative therapies in burn management. ${ }^{6-9}$ For example moist exposed burn ointment which is an herbal remedy for burn treatment was developed and used in China. ${ }^{10,11}$ Saffron (Crocus sativus) extract was used for healing of second-degree burn wounds in rats. ${ }^{12}$ Green tea extract was effective for treatment of second degree burn wounds. ${ }^{13}$ There are other studies supporting the effect of herbal remedies in treatment of burn wounds. ${ }^{14-20}$ Traditionally, an extract from the leaves of a plant called $M$. pulegium has been used to alleviate first and second degree burn wounds in north rural areas of Iran. This study was conducted to evaluate the effect of $M$. pulegium extract on second degree burn injuries in rats.

\section{MATERIALS AND METHODS}

M. pulegium extract was obtained by maceration method. Leaves of $M$. pulegium were converted to a powder by grinding. About $20 \mathrm{~g}$ of powder were mixed with $300 \mathrm{ml}$ ethanol $(70 \%)$ at room temperature for $48 \mathrm{~h}$. Then, the mixture was filtered from paper-making machine to extract the liquid. After preparing the liquid extract, it was placed in 10 plates in a water bath for $48 \mathrm{~h}$ at $70^{\circ} \mathrm{C}$ temperature until it was completely dried. Then, $2 \mathrm{~g}$ of alcoholic extract of M. pulegium was mixed with $100 \mathrm{ml}$ saline; and finally $2 \%$ of the alcoholic extract of $M$. pulegium was obtained. This extract was standardized.

In this experimental study, 30 Wistar albino rats weighing approximately 300-350 g were used. All the rats were healthy and they were screened for animal diseases by a veterinarian. The rats were kept in separate shelves in the animal laboratory with $12 \mathrm{~h}$ light-dark cycle and temperature of $22^{\circ} \mathrm{C}$ ad libitum. All animals were housed in sterilized containers. They were randomly divided into three groups (M. pulegium extract, vaseline, and simple dressing) with 10 rats in each. To create a burn wound in animals, the rats were anesthetized by intramuscular injection of ketamine $(60 \mathrm{mg} / \mathrm{kg})$ and xylazine (10 $\mathrm{mg} / \mathrm{kg}$ ). After shaving their backs hair by a blade, a deep second degree burn wound was created by a metal cube with dimensions of $2 \times 3 \times 1 \mathrm{~cm}$ that was heated to $105^{\circ} \mathrm{C}$ for 15 seconds and an area of about $6 \mathrm{~cm}^{2}$ was burned. Thereafter, treatment was initiated for these three groups with different materials.

The animals were resuscitated with an intraperitoneal injection of $5 \mathrm{ml}$ normal saline solution. Dressings were performed on days 1,3 , 7 , and $14^{\text {th }}$. The rats were given anesthesia while taking photos and also during dressing change. Each test animal was held in a good position and wound margin was traced on a transparent plastic sheet using a fine-tipped pen. The wounds were measured by a ruler on each rat and recorded. Thereafter, photographs of burned areas were taken using a digital camera (Canon power-shot D10) on days 1, 3, 7, 14 and $21^{\text {st }}$. Sizes and areas of burn surface were measured by a standard metric and displayed as $\mathrm{cm}^{2}$ using the software Image $\mathrm{J}$ on each experiment day.

The area of the wounds on the first day was considered as $100 \%$ and wound areas on subsequent days were compared with the wound area on the initial days. Re-epithelialization was evaluated on days $1,3,7,14$ and $21^{\text {st }}$ (the last day of treatment period). For this purpose, skin tissue samples were taken for histological studies with a small excision containing part of the wound area. Tissues were fixed in 10\% formalin. Paraffin-embedded sections (5- $\mu$ m thick) were prepared and stained with hematoxylin and eosin. Light microscopy was used to evaluate the pathological changes, e.g., granulation tissue formation and re-epithelialization in wounds and their comparison with the normal tissue.

The severity of inflammation in treated areas was evaluated by counting the number of inflammatory cells (neutrophils, lymphocytes, and fibroblasts) in 4 different fields (x100) using an ocular micrometer and the mean number of these 4 fields was recorded. The number of blood vessels was counted in 4 different fields (x400) and the mean number was recorded (Table 1). All data were analyzed using statistical software 
Table 1: Comparison of parameters indicating healing of the burn wound in 3 different groups on days 1, 3, 7, 14 and 21.

\begin{tabular}{|c|c|c|c|c|c|c|}
\hline Parameters & Days & $\begin{array}{l}\text { Case group } \\
\text { (treated with } \\
\text { MPE) }\end{array}$ & $\begin{array}{l}\text { "Vaseline } \\
\text { treated group }\end{array}$ & $\begin{array}{l}\text { "Simple dressing } \\
\text { (treated with normal } \\
\text { saline) }\end{array}$ & ${ }^{*}$ P value ${ }^{1}$ & $* * P$ value ${ }^{2}$ \\
\hline \multirow[t]{5}{*}{ Neutrophils } & 1 & $14 \pm 3.2$ & $15 \pm 4.1$ & $14 \pm 2.6$ & 0.32 & 0.93 \\
\hline & 3 & $12 \pm 2.4$ & $14 \pm 2.3$ & $12 \pm 1.4$ & 0.46 & 0.85 \\
\hline & 7 & $11 \pm 2.2$ & $12 \pm 3.1$ & $12 \pm 2.6$ & 0.43 & 0.37 \\
\hline & 14 & $10 \pm 3.6$ & $11 \pm 2.2$ & $11 \pm 3.7$ & 0.52 & 0.61 \\
\hline & 21 & $8 \pm 2.2$ & $10 \pm 3.4$ & $11 \pm 2.8$ & 0.63 & 0.32 \\
\hline \multirow[t]{5}{*}{ Lymphocytes } & 1 & $9 \pm 3.1$ & $9 \pm 3.4$ & $9 \pm 3.5$ & 0.59 & 0.53 \\
\hline & 3 & $10 \pm 2.5$ & $9 \pm 2.2$ & $8 \pm 3.1$ & 0.23 & 0.09 \\
\hline & 7 & $12 \pm 3.1$ & $10 \pm 2.6$ & $10 \pm 2.1$ & 0.16 & 0.22 \\
\hline & 14 & $17 \pm 3.2$ & $14 \pm 2.1$ & $12 \pm 2.3$ & 0.28 & 0.08 \\
\hline & 21 & $32 \pm 2.4$ & $25 \pm 1.5$ & $21 \pm 2.6$ & 0.12 & 0.07 \\
\hline \multirow[t]{5}{*}{ Fibroblasts } & 1 & $6 \pm 2.6$ & $5 \pm 2.2$ & $4 \pm 2.3$ & 0.43 & 0.21 \\
\hline & 3 & $14 \pm 3.3$ & $12 \pm 2.4$ & $12 \pm 2.1$ & 0.51 & 0.62 \\
\hline & 7 & $19 \pm 2.5$ & $14 \pm 3.2$ & $10 \pm 2.5$ & 0.39 & 0.18 \\
\hline & 14 & $25 \pm 3.2$ & $22 \pm 2.1$ & $19 \pm 3.1$ & 0.08 & 0.05 \\
\hline & 21 & $34 \pm 2.8$ & $28 \pm 3.5$ & $23 \pm 3.6$ & 0.07 & 0.04 \\
\hline \multirow[t]{5}{*}{ Angiogenesis } & 1 & $2 \pm 1.1$ & $1 \pm 0.05$ & $1 \pm 0.2$ & 0.62 & 0.74 \\
\hline & 3 & $4 \pm 1.8$ & $3 \pm 1.5$ & $3 \pm 2.4$ & 0.53 & 0.24 \\
\hline & 7 & $7 \pm 2.2$ & $6 \pm 2.1$ & $5 \pm 2.8$ & 0.65 & 0.41 \\
\hline & 14 & $7 \pm 1.5$ & $6 \pm 2.7$ & $6 \pm 2.1$ & 0.73 & 0.62 \\
\hline & 21 & $10 \pm 3.2$ & $8 \pm 2.3$ & $8 \pm 3.3$ & 0.09 & 0.15 \\
\hline \multirow{5}{*}{$\begin{array}{l}\text { Granulation } \\
\text { tissue }\end{array}$} & 1 & $1 \pm 0.15$ & $1 \pm 0.05$ & $1 \pm 0.03$ & 0.92 & 0.86 \\
\hline & 3 & $2.1 \pm 0.25$ & $1.4 \pm 0.14$ & $1.5 \pm 0.22$ & 0.44 & 0.83 \\
\hline & 7 & $1.2 \pm 0.45$ & $1.1 \pm 0.12$ & $1 \pm 0.02$ & 0.72 & 0.66 \\
\hline & 14 & $0.8 \pm 0.15$ & $0.5 \pm 0.32$ & $0.3 \pm 0.02$ & 0.36 & 0.08 \\
\hline & 21 & $0.5 \pm 0.20$ & $0.4 \pm 0.15$ & $0.2 \pm 0.35$ & 0.67 & 0.34 \\
\hline
\end{tabular}

${ }^{\#}$ All values are depicted in Means \pm SD. *The statistical difference between MPE treated group and Vaseline treated group. ${ }^{*}$ The statistical difference between MPE treated group and Simple dressing (normal saline) group. ${ }^{1,2} \mathrm{P}$ value less than 0.05 is considered statistically significant.

SPSS (version 18; Chicago, Illinois, USA). Oneway ANOVA test was used to compare means. A $p$ value less than 0.05 was considered as significant. This study was confirmed by the Ethic Committee of Iran University of Medical Sciences, Tehran, Iran.

\section{RESULTS}

Histological findings indicated a progressive improvement in wound healing during 21 days after starting treatment. The slides from M. pulegium extract treated wounds showed significant wound healing with completed re-epithelialization of epidermis. On day $1^{\text {st }}$ post-burn, epidermis became necrotic due to coagulation. Necrotic basal layer cells were seen arranged in column-fencing formation. Edema was present between epidermis and dermis. Collagenous fibers in the superficial layer of dermis were denatured, swollen and loosely arranged while epithelia of the dermal adnexal epithelia were also denatured. Contracted nucleoli of capillary endothelium, blood clot or stasis in lumen with little infiltration of neutrophil were observed. Only collagenous fibers and dermal appendages in deep layer of dermis were approximately normal (Figure 1).

On day 3 post-burn, necrotic epidermal cells progressed to vacuolation with mild edema between epidermal and dermal layers. Collagenous fibers in the superficial dermis had hyaline degeneration in deep tissue, structure was loose, and blood vessels were slightly swollen with congestion. Scattered inflammatory cells (mainly neutrophils) infiltrated the tissue (Figure 2).

On day $7^{\text {th }}$ when necrotic epidermis exfoliated, superficial tissues in the dermis liquefied and loosened due to necrosis and neutrophilic infiltration (occasional lymphocyte and mononuclear-macrophages) and granulation 


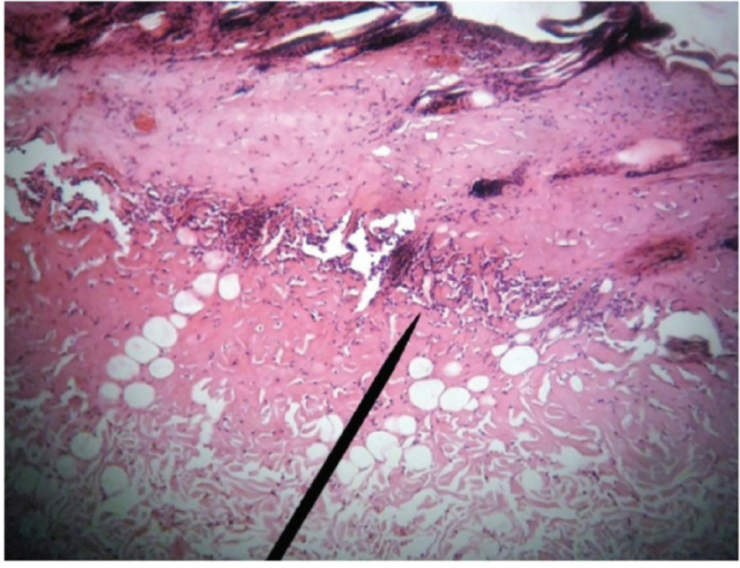

Fig. 1: Microscopic view of burned area in day $1^{\text {st }}$ post-burn. Increased necrosis area, inflammatory cells accumulation above necrotic area and fibrin clot are visible $(\mathrm{H} \& \mathrm{E}, \times 400)$.

tissue formation (Figure 3). On day $14^{\text {th }}$ postinjury, an inflammatory exudation layer replaced the necrotic layer whose liquefaction was now accomplished. The underlying residual adnexal epithelia, fibroblasts and endothelia showed active proliferation. The new epithelium layer was seen (Figure 4).

On day $21^{\text {st }}$ post-burn, regenerated "epithelial islands" grew vertically, then migrated toward and covered the wounds. Neo-formed capillaries were noticed and granulation tissues were formed. The infiltration of inflammatory cells (mainly lymphocytes) in the dermis was still present, especially in the periphery of the regenerated skin appendages. After healing, regenerated skin appeared to be almost normal in structure and majority of skin appendages were restored completely. Infiltration of certain inflammatory cells and few macrophages in

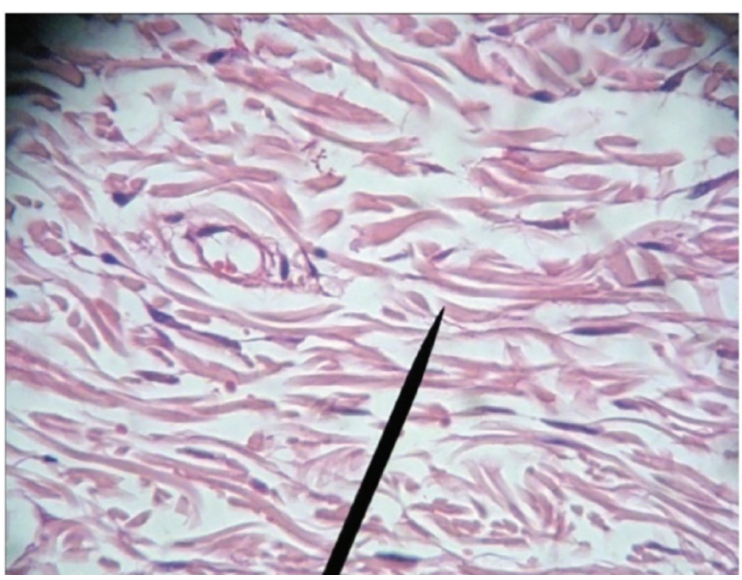

Fig. 3: Microscopic view of burned area in case group on $7^{\text {th }}$ day after treatment which depicts granulation tissue formation, collagen fibrils and fibroblasts (H\&E, ×400).

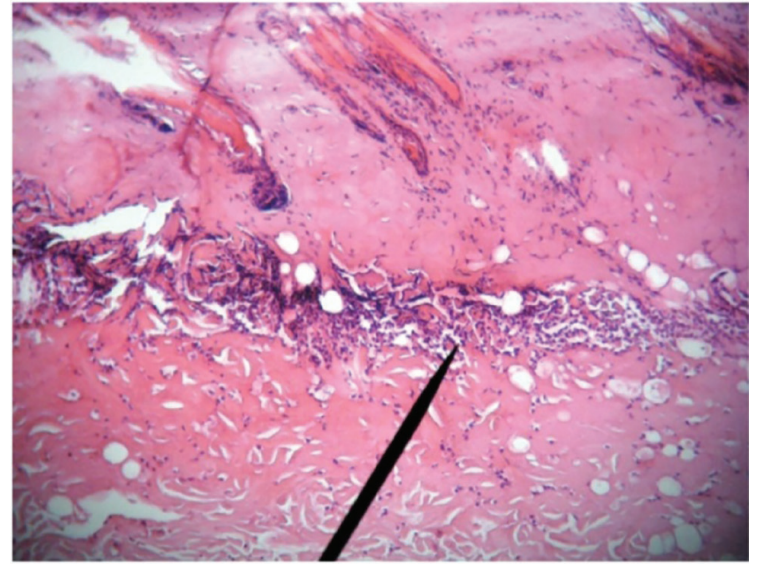

Fig. 2: Microscopic view of burned area in case group on $3^{\text {rd }}$ day after treatment which depicts full thickness skin necrosis and accumulation of inflammatory cells $(\mathrm{H} \& \mathrm{E}, \times 100)$.

dermis persisted (Figure 5).

Comparison of parameters indicating healing of the burn wound (angiogenesis, granulation formation, inflammatory cells and fibroblasts) in these 3 different groups on days 1,3, 7, 14 and $21^{\text {st }}$ were shown in Table 1 . Burned areas were evaluated and compared on days 1, 3, 7, 14 and $21^{\text {st }}$. The evident difference of healing process was observed after day $14^{\text {th }}$ (Table 2). Average burned area was reduced significantly in the group who was treated with M. pulegium extract. The average burned area was statistically significant between $M$. pulegium extract treated group and simple dressing group $(p=0.03)$; however, there was no statistically significant difference between $M$. pulegium extract and vaseline treated groups. Improvement of burn wounds using M. pulegium extract was shown in Figure 6.

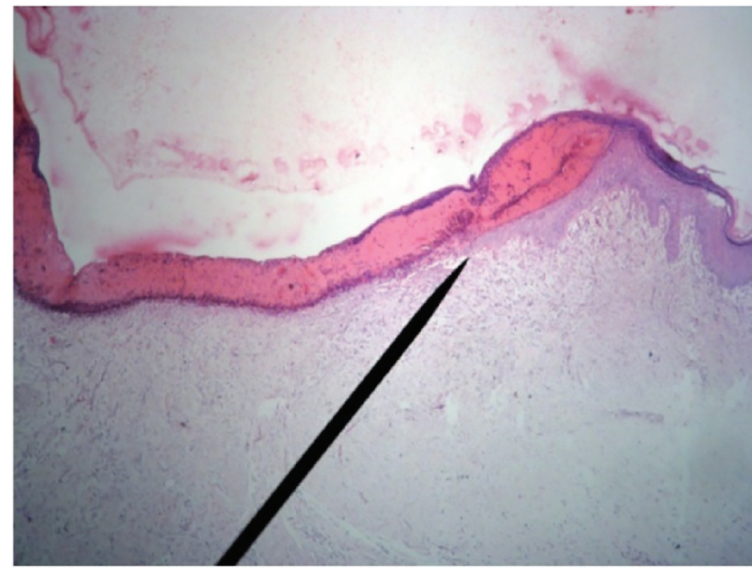

Fig. 4: Microscopic view of burned area in case group at $14^{\text {th }}$ day after treatment which depicts newly formed epithelium $(H \& E, \times 40)$. 
Table 2: Comparison of Burned Surface Areas (BSA) in 3 groups in days 1, 3, 7, 14 and 21.

\begin{tabular}{llllll}
\hline $\begin{array}{l}\text { Burned Surface Area } \\
\text { (BSA) }\end{array}$ & $\begin{array}{l}\text { Mentha } \\
\text { pulegium }\end{array}$ & $\begin{array}{l}\text { Vaseline } \\
\text { ointment }\end{array}$ & Simple dressing & *P value $^{1}$ & **P value $^{2}$ \\
\hline BSA $\left(\mathrm{cm}^{2}\right)$ day 1 & & & & 0.72 & 0.84 \\
Mean & 5.72 & 5.22 & 5.41 & & \\
N & 10 & 10 & 10 & \\
Std & 2.25 & 1.74 & 2.31 & \\
Min & 4.41 & 4.29 & 4.25 & \\
Max & 7.29 & 7.53 & 7.41 & \\
BSA $\left(\mathrm{cm}^{2}\right)$ day 3 & & & & \\
Mean & 4.26 & 5.11 & 5.22 & \\
N & 10 & 10 & 10 & \\
Std. & 1.26 & 1.93 & 1.62 & \\
Min & 4.37 & 4.11 & 4.15 & \\
Max & 5.52 & 7.21 & 7.25 & \\
BSA $\left(\mathrm{cm}^{2}\right)$ day 7 & & & & \\
Mean & 3.21 & 4.67 & 4.87 & \\
N & 10 & 10 & 10 & \\
Std. & 1.58 & 1.33 & 1.17 & \\
Min & 2.91 & 2.89 & 5.73 & \\
Max & 4.83 & 5.66 & 5.96 & \\
BSA $\left(\mathrm{cm}^{2}\right)$ day 14 & & & & \\
Mean & 2.35 & 3.38 & 4.27 & \\
N & 10 & 10 & 10 & \\
Std. & 1.82 & 1.23 & 1.53 & \\
Min & .38 & 2.50 & 2.84 & \\
Max & 3.29 & 4.78 & 5.36 & \\
BSA $\left(\mathrm{cm}^{2}\right)$ day 21 & & & & \\
Mean & 1.12 & 2.63 & 3.78 & \\
N & 10 & 10 & 10 & \\
Std. & 0.42 & 1.83 & 1.64 & \\
Min & .00 & 2.50 & 2.84 & \\
Max & 1.82 & 3.63 & 4.41 & \\
\hline
\end{tabular}

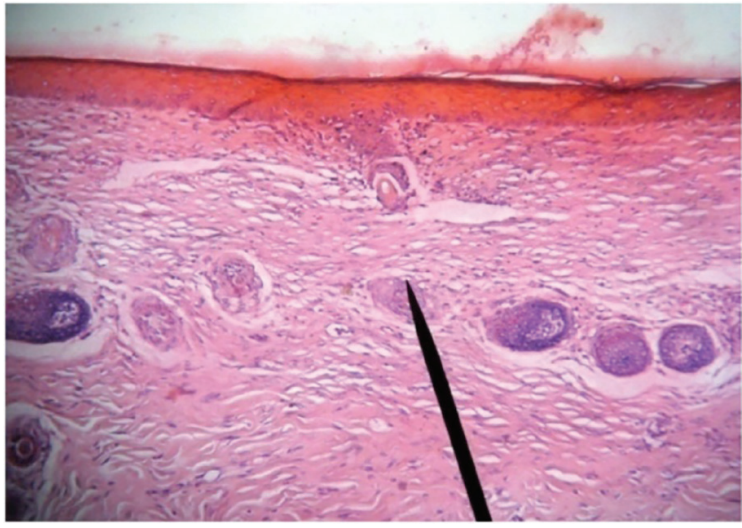

Fig. 5: Microscopic view of burned area in case group at day $21^{\text {st }}$ after treatment which depicts completely formed epithelium $(\mathrm{H} \& \mathrm{E}, \times 100)$.

\section{DISCUSSION}

The study results indicated a staged pathological change of burn wound when treated with M. pulegium extract. Burn area decreased significantly in M. pulegium extract treated group. Our results showed that topical application of $M$. pulegium extract was efficacious in treatment of second degree burn wounds in comparison to vaseline and simple (normal saline) dressings. At the end of the study (day 21 $1^{\text {st }}$ ), microscopic and macroscopic findings indicated that treatment of deep second-degree burn wounds with M. pulegium extract results in physiological regeneration with minimal scar formation.

M. pulegium commonly known as pennyroyal belongs to the Mentha species is a native species found in Europe, North Africa and in Asia Minor and near East. ${ }^{19}$ Previous studies have shown that $M$. pulegium has antioxidative, antimicrobial, spasmolytic and relaxant activities. $^{20-23}$ The effect of M. pulegium on improvement of the burn lesion can be attributed to any of the aforementioned effects or all of them together. The relaxant and spasmolytic effects of M. pulegium have been ascribed to the 

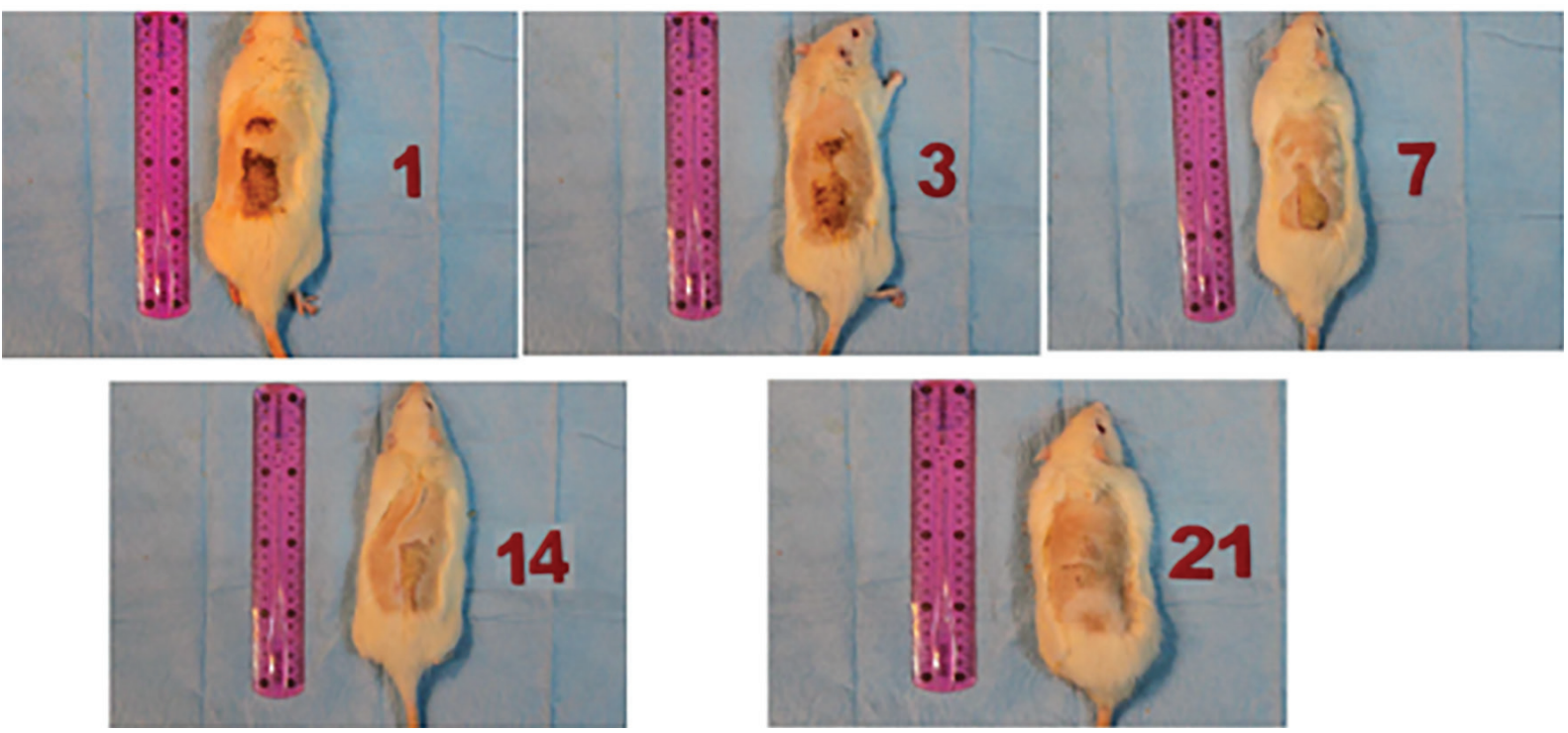

Fig. 6: Progressive improvement of burn wound in rats treated with Mentha pulegium extract.

"Pulegone" which possibly relaxes the smooth muscles via increasing the participation of extracellular calcium. Stimulation of calcium sensitive potassium channels hyperpolarize the cell and causes relaxation. The relaxation of the smooth muscles in the vessels' walls will increase the blood perfusion to the injured tissue. Antimicrobial effect of the M. pulegium has been studied in vitro using its oil extract. ${ }^{24}$

The antimicrobial activity of $M$. pulegium has been attributed to Piperitone and Piperitenone which have activity against Gram-positive bacteria especially Staphylococcus aureus. ${ }^{23}$ It has also been shown that piperitone completely inhibited Aspergillus flavus. ${ }^{25}$ M. pulegium has been shown to be effective as a protoscolicidal agent too and it killed Echinococcus granulosus proroscoleces. ${ }^{26}$ The antioxidant activity of $M$. pulegium also helps to facilitate and accelerate the improvement of burn tissue by increasing the activity of superoxide dismutase and glutation peroxidase. ${ }^{27}$

There is another study on naturally-derived products in treatment of burn wounds which showed healing effect of biomaterials in first and second degree burn wounds. For example, in a case-control study by Gupta and colleagues, honey dressing sterilized the wounds in less time, enhanced healing and had a better result in treating hypertrophic scars and postburn contractures in comparison to silver sulfadiazine. ${ }^{6}$ Scientists in China developed an alternative therapy for treating burn wounds as herbal remedy which was named moist exposed burn ointment. They claimed that it was ideal wound dressing option for burns. ${ }^{11}$

Thereafter, numerous studies have been conducted using moist exposed burn ointment for burn treatment. These studies claimed that moist exposed burn ointment can reduce wound healing time, bacterial colonization, and the need for analgesics or antibiotics and also it results in a better aesthetic outcome. Moist exposed burn ointment is an oil-based ointment composed of sesame oil and some other plant ingredients. ${ }^{10,11,14-16}$ However, in our study, the simple dressing which was a combination of a sterile gauze and normal saline did not show any significant improvement in burn wounds. Therefore, the moisture alone is not a factor for improvement of burn wounds. There should be an antioxidant and antimicrobial effects of moist exposed burn ointment that helps improving the burn wounds. It was clarified that antiinflammatory and antimicrobial effects of moist exposed burn ointment was due to beta-sitosterol and berberine, respectively. ${ }^{28}$

Alternative medicine has been used in treating burn wounds since ancient times. Herbal products such as moist exposed burn ointment, Aloe vera, Aloe littoralis, Aloe saponaria haw and green tea have been effective in treatment of burn injuries in animal models..$^{10-18,28,29}$ On the other hand, using stem cells or skin grafts in burn injuries is costly and limited for developing countries, therefore, alternative therapies for second degree burn wounds has become a reasonable modality for cure. ${ }^{30}$ Our results showed that M. pulegium 
extract was beneficial in treating second degree burn injuries, but the side effects of this product are not yet determined. Also we are intending to determine the main ingredients and substances in M. pulegium which may contribute to its wound healing effects and formulize a biomaterial for treatment of second degree burn wounds.

\section{ACKNOWLEDGMENT}

We would like to thank Iran University of Medical Sciences for financial support.

\section{CONFLICT OF INTEREST}

The authors declare no conflict of interest.

\section{REFERENCES}

1 World Health Organization. The Global Burden of Disease: 2004 Update. Geneva: WHO; 2008.

2 Bhattacharya S. Principles and practice of Burn care. Indian J Plast Surg 2009;42:275.

3 Control CfD, Prevention. National hospital discharge survey: 2010. Selected Data Tables (Accessed on 2 December 2014). Available from: http://www cde gov/nchs/nhds/nhds tables htm\# number

4 Santaniello JM, Luchette FA, Esposito TJ, Gunawan H, Reed RL, Davis KA, Gamelli RL. Ten year experience of burn, trauma, and combined burn/trauma injuries comparing outcomes. J Trauma 2004;57:696-700; dicussion -1 .

5 Sadeghi-Bazargani H, Mohammadi R. Epidemiology of burns in Iran during the last decade (2000-2010): review of literature and methodological considerations. Burns 2012;38:319-29. doi: 10.1016/j. burns.2011.09.025.

6 Akhoondinasab MR, Akhoondinasab M, Saberi M. Comparison of healing effect of aloe vera extract and silver sulfadiazine in burn injuries in experimental rat model. World J Plast Surg 2014;3:29-34.

7 Nasiri E, Hosseinimehr SJ, Azadbakht M, Akbari J, Enayati-Fard R, Azizi S, Azadbakht M. The Healing Effect of Arnebia Euchroma Ointment versus Silver Sulfadiazine on Burn Wounds in Rat. World J Plast Surg 2015;4:134-44.

8 Varaei S, Mohaddes Ardabili F, Sabaghzadeh
Irani P, Ranjbar H. The Effect of Aloe Vera Gel and Nitrofurazone on Dressing Related Pain of Superficial Burn Wounds. World $J$ Plast Surg 2017;6:254-6.

9 Mohtasham Amiri Z, Tanideh N, Seddighi A, Mokhtari M, Amini M, Shakouri Partovi A, Manafi A, Hashemi SS, Mehrabani D. The Effect of Lithospermum officinale, Silver Sulfadiazine and Alpha Ointments in Healing of Burn Wound Injuries in Rat. World J Plast Surg 2017;6:313-8.

10 Jewo PI, Fadeyibi IO, Babalola OS, Saalu LC, Benebo AS, Izegbu MC, Ashiru OA. A Comparative Study of the Wound Healing Properties of Moist Exposed Burn Ointment (MEBO) and Silver Sulphadiazine. Ann Burns Fire Disasters 2009;22:79-82.

11 Ang ES, Lee ST, Gan CS, See P, Chan YH, Ng LH, Machin D. The role of alternative therapy in the management of partial thickness burns of the face--experience with the use of moist exposed burn ointment (MEBO) compared with silver sulphadiazine. Ann Acad Med Singapore 2000;29:7-10.

12 Khorasani G, Hosseinimehr SJ, Zamani P, Ghasemi M, Ahmadi A. The effect of saffron (Crocus sativus) extract for healing of second-degree burn wounds in rats. Keio $J$ Med 2008;57:190-5. doi: 10.2302/kjm.57.190.

13 Fatemi MJ, Nikoomaram B, Rahimi AA, Talayi D, Taghavi S, Ghavami Y. Effect of green tea on the second degree burn wounds in rats. Indian J Plast Surg 2014;47:370-4. doi: 10.4103/0970-0358.146593.

14 Akbari H, Fatemi MJ, Iranpour M, Khodarahmi A, Baghaee M, Pedram MS, Saleh S, Araghi S. The healing effect of nettle extract on second degree burn wounds. World J Plast Surg 2015;4:23-8.

15 Atiyeh BS, Ioannovich J, Magliacani G, Masellis M, Costagliola M, Dham R, AlFarhan M. Efficacy of moist exposed burn ointment in the management of cutaneous wounds and ulcers: a multicenter pilot study. Ann Plast Surg 2002;48:226-7. doi: 10.1097/00000637-200202000-00032.

16 Shahouzehi B, Sepehri G, Sadeghiyan S, Masoomi-Ardakani Y. Effect of Pistacia Atlantica Resin Oil on Anti-Oxidant, Hydroxyprolin and VEGF Changes in Experimentally-Induced Skin Burn in Rat. World Journal of Plastic Surgery 2018;7:2-8.

17 Asgarirad H, Chabra A, Rahimnejad M, Zaghi 
Hosseinzadeh A, Davoodi A, Azadbakht M. Comparison of Albizia Julibressin and Silver Sulfadiazine in Healing of Second and Third Degree Burns. World J Plast Surg 2018;7:34-44.

18 Vaghardoost R, Mousavi Majd SG, Tebyanian $\mathrm{H}$, Babavalian H, Malaei L, Niazi M, Javdani A. The Healing Effect of Sesame Oil, Camphor and Honey on Second Degree Burn Wounds in Rat. World J Plast Surg 2018;7:67-71.

19 Mikaili P, Mojaverrostami S, Moloudizargari M, Aghajanshakeri S. Pharmacological and therapeutic effects of Mentha Longifolia L. and its main constituent, menthol. Anc Sci Life 2013;33:131-8. doi: 10.4103/0257-7941.139059.

20 Kamkar A, Javan AJ, Asadi F, Kamalinejad $M$. The antioxidative effect of Iranian Mentha pulegium extracts and essential oil in sunflower oil. Food Chem Toxicol 2010;48:1796-800. doi: 10.1016/j.fct.2010.04.003.

21 Shahmohamadi R, Sariri R, Rasa M, Aghamali M. Antioxidant activity of gilan Mentha pulegium during growth. Pak J Biol Sci 2014;17:380-7. doi: 10.3923/pjbs.2014.380.387.

22 Ibrahim AK. New terpenoids from Mentha pulegium L. and their antimicrobial activity. Nat Prod Res 2013;27:691-6. doi: 10.1080/14786419.2012.691488.

23 Mahboubi M, Haghi G. Antimicrobial activity and chemical composition of Mentha pulegium L. essential oil. J Ethnopharmacol 2008;119:325-7. doi: 10.1016/j.jep.2008.07.023.

24 Soares PM, de Freitas Pires A, de Souza EP, Assreuy AM, Criddle DN. Relaxant effects of the essential oil of Mentha pulegium L. in rat isolated trachea and urinary bladder.
J Pharm Pharmacol 2012;64:1777-84. doi: 10.1111/j.2042-7158.2012.01558.x.

25 Cardenas-Ortega NC, Zavala-Sanchez MA, Aguirre-Rivera JR, Perez-Gonzalez C, Perez-Gutierrez S. Chemical composition and antifungal activity of essential oil of Chrysactinia mexicana gray. J Agric Food Chem 2005;53:4347-9. doi: 10.1021/jf040372h.

26 Maggiore MA, Albanese AA, Gende LB, Eguaras MJ, Denegri GM, Elissondo MC. Anthelmintic effect of Mentha spp. essential oils on Echinococcus granulosus protoscoleces and metacestodes. Parasitol Res 2012;110:1103-12. doi: 10.1007/s00436011-2595-x.

27 Alpsoy L, Sahin H, Karaman S. Anti-oxidative and anti-genotoxic effects of methanolic extract of Mentha pulegium on human lymphocyte culture. Toxicol Ind Health 2011;27:647-54. doi: 10.1177/0748233710393402.

28 Carayanni VJ, Tsati EG, Spyropoulou GC, Antonopoulou FN, Ioannovich JD. Comparing oil based ointment versus standard practice for the treatment of moderate burns in Greece: a trial based cost effectiveness evaluation. BMC Complement Altern Med 2011;11:122. doi: 10.1186/1472-6882-11-122.

29 Hajhashemi V, Ghannadi A, Heidari AH. Anti-inflammatory and wound healing activities of Aloe littoralis in rats. Res Pharm Sci 2012;7:73-8.

30 Sedighi A, Mehrabani D, Shirazi R. Histopathological evaluation of the healing effects of human amniotic membrane transplantation in third-degree burn wound injuries. Comp Clin Path 2016;25:381-5. 